\title{
IMPROVING RELATIONSHIP QUALITY: A RELATIONAL MODEL OF INTERNAL MARKETING AND COMMITMENT TO CUSTOMER SERVICE IN HIGHER EDUCATION
}

\section{Yessy Artanti ${ }^{1 *}$, Sri Hartini ${ }^{2}$, Widyastuti ${ }^{3}$, Nindria Untarini ${ }^{4}$}

$1^{1 * 3,4}$ Department of Management, Faculty of Economics, Universitas Negeri Surabaya, Surabaya, Indonesia and Student of Ph.D. Program, Department of Management, Faculty of Economics and Business, Universitas Airlangga, Surabaya, Indonesia; ${ }^{2}$ Department of Management, Faculty of Economics and Business, Universitas Airlangga Surabaya, Indonesia.

Email: ${ }^{1 *}$ yessyartanti@unesa.ac.id, ${ }^{2}$ hartini_unair@yahoo.com, ${ }^{3}$ widyastuti@unesa.ac.id, ${ }^{4}$ nindriauntarini@unesa.ac.id Article History: Received on $19^{\text {th }}$ February 2020, Revised on $27^{\text {th }}$ May 2020, Published on $4^{\text {th }}$ July 2020

\section{Abstract}

Purpose: This study aims to the mediating effects of commitment to customer service on the internal marketing and relationship quality of higher education institutions. Internal marketing is accessed by internal communication and training.

Methodology: The population of this research is the staff of the public service sector, especially employees in universities at Surabaya, East of Java, Indonesia. Researchers surveyed 220 employees in both private and public universities who have worked with a minimum period of 5 (five) years. These samples were selected by judgment sampling method and Path Analysis was employed to analyze data.

Main Findings: Results identified internal communication and training influenced commitment to customer service which further influenced their relationship quality.

Application of this study: Internal marketing practice is essential to explaining the commitment to customer service and relationship quality, especially in the higher education institutions.

Novelty/Originality of this study: To the best, our knowledge is seen from testing the effects of internal marketing on two types of internal marketing outcomes and the selection of university as the object of study.

Keywords: Relationship Quality, Internal Marketing, Internal Communication, Training, Commitment to Customer Service, Higher Education Institutions.

\section{INTRODUCTION}

Higher education service is essential to the development in social, economic, and infrastructure sectors. The effectiveness, efficiency, and quality of education service affect not only the students but also the community in general. As a public sector organization, higher education institutions face the demand to create and provide the value of the community through the improvement of service, processes, engagements, objectives, and strategies (Arleen et al., 2017). Higher education institutions, particularly universities, encounter the challenges of creating value through superior service with certain limitations including regulations and budget. Service quality is inseparable from the physical contacts between salespersons (in this case is employees) and customers in the service environment that continually $\&$ significantly develop and contribute to customer perception of service quality. Thereby, the exploration of elements in the organization and its contribution to supporting the interaction of employees (salespersons) and customers continue to be conducted, for instance, to organizational structure (Conduit and Mavondo, 2001), interpersonal relationship, reward, and resource allocation (Morrison, 1996). The activities in building the internal relationship of the organization frequently turn into a central topic in the internal marketing and service literature.

Berry (2002) mentions that internal marketing is one relationship marketing strategy needed to be considered in a longterm relationship plan for customers. Furthermore, Berry (2002) proposes that internal marketing is relevant to nearly all organizations. For a service company, for example, the service quality on sale will be determined by the practical skill and attitude to the employees who produce service. For this reason, service-oriented companies may use internal marketing to attract, retain, and motivate their employees' quality by continuously improving their ability to provide service quality. Offering products (goods and services) that consistently meet quality requirements is also a crucial factor in building reliable relationship marketing in each organization. Internal marketing is the best approach to build a service-oriented organization. Internal marketing focuses on useful internal organizational achievements, exchanges with organizations and employees as a prerequisite for the successful external exchange.

Academics have widely used internal marketing in describing relationships to the organizations that see employees as partners for them as an effort to achieve organizational success. Organizations that view employees as the most valuable asset will treat them as internal customers in order to gain a competitive and objective advantage (Rafiq and Ahmed, 2000). Service to internal customers is an essential part of creating organizational success. The internal marketing relevance to service operation is found in the service quality improvement in customer-oriented companies. Several previous studies have found that internal marketing affects several outcomes, both in individuals (customers and 
employees) and organizational levels.

Several researchers have developed different internal marketing definitions and their contribution to various outcomes. The developing vital ideas include the effects of internal marketing on employees (Ahmed et al., 2002; Berry, 1981; Mudie, 2003; Rafiq and Ahmed, 2000); the effects of internal marketing on organizations (Ahmed et al., 2002; Mudie, 2003); the effects of internal marketing on external customer satisfaction_Ahmed and Rafiq, 2014; Rafiq and Ahmed, 2000); and the effects of internal marketing on the development of cross-functional units in the organizations (Ahmed and Rafiq, 2003; Ballantyne, 2003; Rafiq and Ahmed, 2000).

Regardless of the summary of the research results, Bansal et al. (2001) point out that there are only a few research studies on the effects of internal marketing activity on external marketing outcomes, such as external service quality, external customer satisfaction, and external customer loyalty. Most of the research on internal marketing tested the effects of internal marketing on internal marketing outcomes, such as work commitment, job satisfaction, trust, and internal customer loyalty. Nevertheless, one should admit that there has not been any research that directly examines the effects of internal marketing on external marketing outcomes. Multiple mediating variables that connect the internal marketing outcome of external marketing outcomes are required. In his research, Bansal et al. (2001) employed internal customer behavior variables, namely extra-role behaviors directed at external customers, which was expected to link the relationship between internal and external marketing outcomes.

The research conducted by Bouranta and G. Mavridoglou (2003) mentioned research results found by some researchers that concluded that internal marketing was able to significantly contribute to the quality improvement provided by some service companies (George, 1990; Berry and Parasuraman, 1991; Piercy, 1995). Subsequently, not only limited to the service industry, the research results by Greene et al. (1994) concluded that internal marketing is fundamentally important to all industries, but its role is more necessary for the service industry. It is supported by the research performed by Bailey et al. (2015) that used service as the research object, namely several banks of Saudi Arabia. They examined the effect of global measurement of internal marketing on job satisfaction and employees' commitment to the banking sector. Moreover, most research on internal marketing is more applicable in service sectors, including banks and other financial services (Ali, 2012; Narteh, 2012; Sahiet al., 2013; Albassami et al., 2015; Du Preez and Bendixen, 2015) as well as restaurants (Salehzadehet al., 2017; Akroushet al., 2012). From an internal marketing perspective, employees in the service industry are crucial factors of the company's success (Joung et al., 2015).

Although service companies are the primary users of the internal marketing concept, this concept applies to non-profit organization sectors and the public sector, including higher education (Altarifi, 2013; Dias and da Silva, 2013, Tareef and Balas, 2012). Finally, through several theories and studies of previous research results, this research is expected to contribute to the service industry, especially for universities, in providing services for customers or students. Furthermore, the researcher seeks to examine the mediating effects of employee commitment to customer service, in the relationship between internal marketing and relationship quality in higher education institutions, particularly in Surabaya, East of Java, Indonesia. It is expected that employees' commitment to customer service is capable of representing the internal outcome of internal marketing, which later will be connected with relationship quality as the external outcome of internal marketing.

The present research is essential to conduct because besides yielding internal and external marketing outcomes, we must admit that despite the significant role of internal marketing in its relationship to organizational external marketing's objectives related to the company's internal capabilities, there are only a few organizations that use the internal marketing concept in their practices. To promote products and maintain their external customers, most companies focus on external marketing activities. Nevertheless, tangible and intangible services are delivered from internal customers (employees) to external customers (students) in the higher education service sector. Also, research on the application of internal marketing concepts, specifically in institutions (universities) is still rarely conducted in Indonesia.

The originality in this research is seen from testing the effects of internal marketing; two types of internal marketing outcomes, internal and external; and the selection of the education service type, universities. The research was carried out based on the model proposed by Bell et al. (2004), Huang et al., (2012), and Huang, Y. T. \& Rundle-Thiele, S. (2015). Several previous studies have found partial relationship between variables as follows: (1) internal communication on commitment to consumer service by Álvarez, L.S., et al., (2009), Frandsen, F. and Johansen, W., (2011), Thomson, K. and Hecker, L., (2001), Kitchen, P.J and Daly, F., (2002), Kollat, J. and Farache, F., (2017), Asif, S. and Sargeant, A, (2000), González, G.B., et al., (2016),Boshoff, C. and Mels, G., (1995), Suh, T. and Lee, J., (2016), Balaji, M.S., et al., (2016), (2) training on commitment to consumer service by Sharma, N. and Patterson, P.G., (1999), Álvarez, L.S., Casielles, R.V. and Martín, A.M.D., (2009), Furtmueller, E., Dick, R.V. and Wilderom, C., (2011), Mouawad, M. and Kleiner, B.H., (1996), Koskela, I. and Palukka, H., (2011), Little, M.K. and Dean, A.M., (2006), Giovanis, A., (2016), Izogo, E.E., (2017), Patwardhan, A. and Patwardhan, P., (2009), Bianchi, C., (2011), (3) commitment to consumer service on relation quality by Sharma, N. and Patterson, P.G., (1999), Moreira, A.C. and Silva, P.M., (2015), Wetzels, M., et al., (1998), Taylor, C., (1994), Jones, T.D., et al., (2009), Little, M.M. and Dean, A.M., (2006), Fullerson, G., (2014), Álvarez, L.S., et al., (2009), Giovanis, A., (2016), Izogo, E.E., (2017).

No previous study has comprehensively studied internal communication and training on a commitment to customer 
service, and commitment to customer service on relationship quality. Keeping mid this point the researcher aimed to find out the mediating effects of commitment to customer service on the internal marketing and relationship quality of higher education institutions. Internal marketing is accessed by internal communication and training.

\section{LITERATURE REVIEW AND HYPOTHESES DEVELOPMENT}

\section{Internal Marketing}

Service industries and service organizations play an essential role in national economic growth (Joung et al., 2015). In service organizations, intangible assets, such as human resources, are at the core of competitive advantage. The investment in human resources and improvements to the internal administration process will promote quality improvement in services (Campo et al., 2014). Internal marketing is a strategy to create high-performing individual values, concerning its indicators of reward systems, internal communications, training, and development, as well as senior leader support to increase superior employee performance, which ultimately will affect the business performance (Ahmed et al., 2003). The symbiotic relationship between the organization and internals customer is aimed at creating individual values that result in increased profitability, customer retention, market share, and organizational performance. When organizations are capable of meeting their needs and desire and providing support to employees, they are more responsible and more focused on achieving their performance (Keller et al., 2006).

The internal marketing concept was first introduced by Berry (1981) and Gronroos (1983) as an approach that allowed and motivated all members of the organization to conduct their responsibility and service. Internal marketing to emphasize that all members of the organization are customers. Thus, the organization should maintain and improve its relationships with its internal customers - the employees - through the quality of internal service (Groonros 1981). In line with the development of subsequent researchers, the elements of internal marketing are also developed. Several researchers mention internal marketing elements, comprising of internal communication (Naude et al., 2003), training (Zampetakis and Moustakis, 2007), and internal market research (Paraskevas, 2001). These three elements are adopted in the work of Huang and Thiele (2013) and Back et al., (2011).

Despite the differences between internal marketing elements, Bell et al. (2004), Back et al., (2011), and Huang and Thiele (2015) agree that the internal marketing process lies in the full and continuous management support. Based on the agreement and adaptation of the marketing context, the present research employs marketing elements of Huang and Thiele (2015) and Back et al. (2011), which consists of internal communication and training.

Similarly, internal marketing towards employees' commitment to customer service (salesperson commitment to customer service). This research employs a research model by Bell et al. (2004) that examines the relationship of internal marketing on salesperson commitment to customer service. In this context, Bell et al. (2004) used social exchange perspectives proposed by Shore and Wayne (1997), stating there is a social exchange of the relationship between employee-organizations. The companies that undertake internal marketing through internal communication, training, and carry out comprehensive internal marketing research will be able to increase employee commitment or employee orientation, particularly in terms of customer service.

Various literature on internal communication agrees that the organization can obtain many benefits if the management is willing to conduct their internal communication effectively (Piercy \& Morgan, 1990). Varey and Lewis (1999) suggest that internal communication is a contract between manager and employee, wherein that relationship the managers must reconsider the rules they created, and think about the things to do for improving the quality of their employees.

Some researchers use internal marketing constructs as an organizational variable or at the level of organizational analysis (Shiu and Yu, 2010; Zaman et al., 2012). Such a variable is measured by Likert scale using the existing scores. However, the scores of the organizational variable will have different values for each response. This research used internal marketing construct measurement, salespersons' commitment to customer service, and the relationship quality perceived by individuals towards those activities. As explained in the background, besides adopting the model used by Huang \&Rundle-Thiele (2015), this research also employs some of the models used by Bell et al. (2004), Huang et al., (2012), and Huang and Thiele (2015). The summary of other research results regarding internal marketing can be seen in Table 1.

Table 1: A Summary of Varying Research Results on Internal Marketing

\begin{tabular}{|c|c|c|c|c|}
\hline Research & Method & Respondents & Variables & Results \\
\hline \multirow[t]{5}{*}{$\frac{\text { Ahmed et }}{\underline{a l .}}$} & Survey & $\begin{array}{c}300 \text { employees of } \\
\text { manufacturing and } \\
\text { services }\end{array}$ & $\begin{array}{l}\text { The internal marketing mix, } \\
\text { organizational competencies, } \\
\text { business performance }\end{array}$ & \multirow{2}{*}{$\begin{array}{l}\text { Internal marketing } \\
\text { has a significant and positive } \\
\text { effect on business performance. } \\
\text { Organizational competence } \\
\text { (individual competencies) }\end{array}$} \\
\hline & & & & \\
\hline & & & & mediates the effect of internal \\
\hline & & & & marketing on business \\
\hline & & & & performance. \\
\hline
\end{tabular}




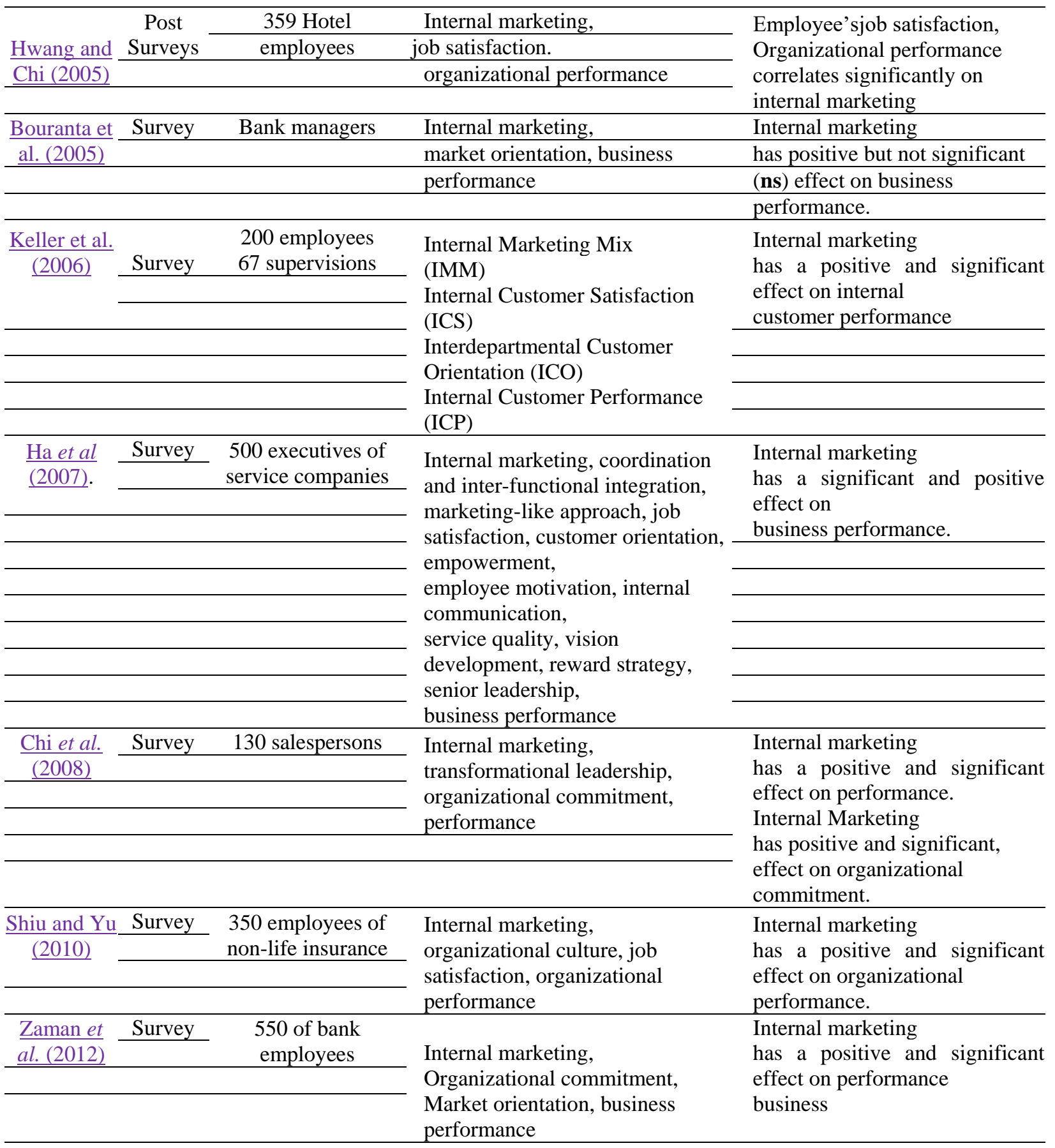

Source: Mapping made from Previous Research

\section{Internal Marketing at Higher Education}

A review of internal marketing literature in higher education demonstrates serious concern in responding to the growing competition and demand for quality education (Stimac and Simic, 2012; Tareef and Balas, 2012). Most research on higher education focuses on communication relationship marketing, service quality, and the various outcomes of the work of teachers or employees. It rarely focuses on non-teaching staff or employees who interact directly with their customers, i.e., the students.

In the higher education institution, the role of employees that provide service to students is a crucial factor in providing service quality. Service quality from employees can at least be provided if the employees feel satisfied with their needs and are treated as a valuable asset of human resources at a higher education institution. The internal marketing concept is present to provide guidance and counseling on how the institutions should treat their employees as customers, i.e., internal customers. Because of Hemsley-Brown and Oplatka (2006), studies on the marketing of higher education are still minimal. Thereby, the researchers feel the need to further investigate the area of internal marketing in higher education institutions like universities. 


\section{Internal Marketing and Commitment to Customer Service}

The concept of internal marketing has been studied for more than 30 years to simply understand how marketing principles can be applied to employees, based on the comprehension that the company's marketing success is more determined by its employees. Several studies have investigated the basics of conceptual training as internal marketing components that can be divided into four main categories: service standard, training, development program, and rewards (Papasolomou\&Vrontis, 2006). Collins \&Payne (1991) identify human resource management and employee training as a primary internal marketing activity, while Paraskevas (2001) states that employees with the necessary skills and information possess a significant role in implementing internal marketing.

Internal marketing, in the opinion of Huang (2015), is divided into internal communication, training, and market research. This division is based on the initial idea of internal marketing proposed by previous studies. Market research was not used in this research because it was adapted to the respondents that became the samples of this research. Based on the description, this research adopted internal communication and training as elements of internal marketing.

H1: Internal communication has a significant effect on commitment to customer service.

H2: Training has a significant effect on commitment to customer service.

\section{Commitment to Customer Service and Relationship Quality}

Concerning to test the commitment to customer service on relationship quality, this research adopted some of the models used by Huang et al. (2012) who tested the effects of internal marketing perceived on the relationship quality and customer loyalty to a perceptual market orientation. The commitment to customer service is an employee's relative tendency to keep improving and driving great efforts in customer benefits' achievement (Peccei and Rosenthal 1997). When employees commit to providing the best service to customers, it will create a relationship quality between customers and employees.

The initial idea of relationship quality surfaces from theories and studies in relationship marketing (Crosby et al., 1990; Dwyer et al., 1987), where the ultimate goal of relationship quality is to strengthen the existing relationship to customers to make them more loyal. Subsequently, the relationship quality is an assessment of the strength of a relationship as a whole, and to the extent to which conformity occurring between the needs and expectations of the parties based on previous experience (Crosby, Evans, \& Cowles, 1990). According to Huang et al. (2013), relationship quality comprises two constructs: the relationship quality between customers and employees and the relationship quality between customers and the organizations.

H3: The commitment to customer service has a significant effect on relationship quality.

Based on the description and analysis of various models above, besides adopting the model used by Huang (2015), this research also used some of the models employed by Bell et al. (2004), Huang et al.,(2012), Huang \& Thiele (2013) and Huang and Thiele (2015), then it yielded the research model below:

Internal Marketing

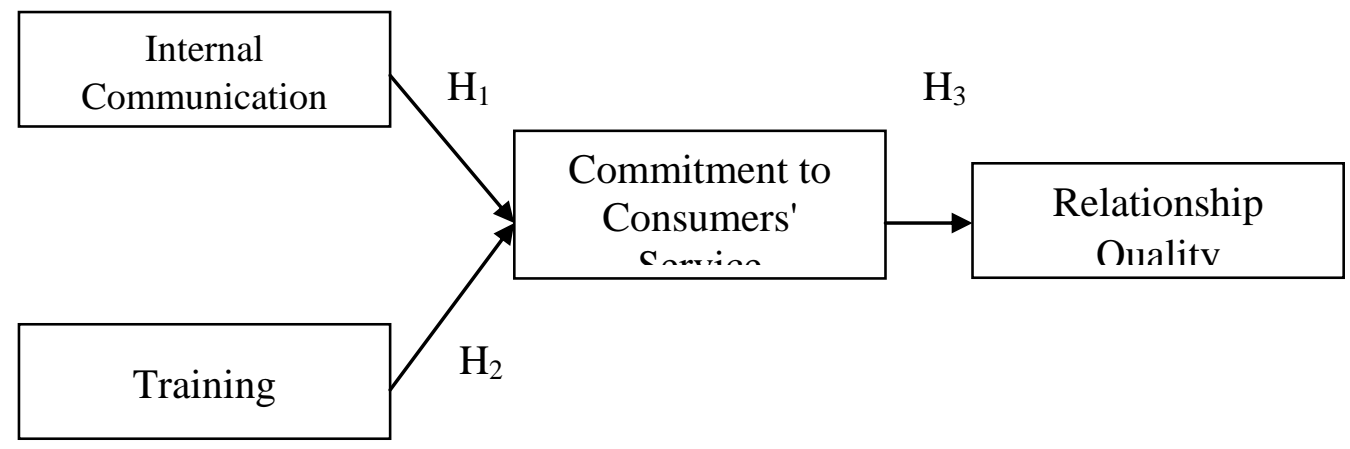

Figure 2: The research model

\section{METHODOLOGY}

The population of this research was some employees in several higher education institutions (universities), both private and public universities in Surabaya, East Java, Indonesia. The present research employed a survey method, where the samples used were 220 university employees. The sampling technique used judgment sampling, using a few requirements, i.e., the employees that had worked in each institution with a minimum working period of 5 (five) years. The scale used to measure the constructs in this research was derived from various available literature, both in the form of theories and previous research results. All items were measured using a 5-point Likert Scale, ranging from 1 (strongly disagree) to 5 (strongly agree). Each scale had undergone validity and reliability testing. 
Internal marketing was measured by adopting instruments developed by several researchers, namely Money and Foreman (1996), Caruana and Calleya (1998), Ewing and Caruana (1999), Naude et al. (2003), Bouranta et al. (2005), Bennett and Barkensjo (2005), Shiu and Yu (2010) consisting of dimensions, internal communication, and training. The internal communication indicators were: (1) two-way communication opportunities, (2) holding regular meetings for service quality, and (3) the supervisors facilitating innovative ideas. While the training indicators were: (1) giving chances to attend training, (2) training to improve service quality, and (3) the provision of information about meeting forums.

Commitment to Customer Service is measured using these indicators: (1) working to improve service quality; (2) having the ideas to improve service quality; (3) giving suggestions to improve service quality, (4) always trying to satisfy customers, 5) always willing to serve the customers under any circumstances.

Relationship quality. Based on the concept developed by Donabedian (1980), this relationship quality measurement also compares the measurement made by Garbarino and Johnson (1999) and Mechanic and Meyer (2000). Eventually, this research employed six items: (1) The university is committed to fulfilling the needs of its employees; (2) The university is consistent with providing quality service; (3) The university offers personalized service to meet the needs of its employees; (4) I believe my superior has high integrity; (5) I believe in things promised by the university; and (6) it is challenging to leave this institution.

\section{Model}

The data collected were analyzed using path analysis. This analysis was used to determine the relationship between independent variables (internal communication and training) and the dependent variable (relationship quality), through the mediating variable (commitment to customer service). Based on the variables used, the relationship between variables can be formulated as follows:

$Z=a+b_{1} X_{1}+b_{2} X_{2}+e_{1}$

$\mathrm{Y}=\mathrm{a}+\mathrm{b}_{3} \mathrm{Z}+\mathrm{e}_{2}$

Description:

Y: Relationship quality

$\mathrm{X}_{1}$ : Internal Communication

$\mathrm{X}_{2}$ : Training

$\mathrm{Z}$ : Commitment to customer service

$\mathrm{b}_{1}, \mathrm{~b}_{2}, \mathrm{~b}_{3}$ : Path coefficient

\section{Measurement Validation}

The respondents in this research are many employees at several universities in Surabaya, East Java, Indonesia. The characteristics of respondents in this research are grouped into several demographic aspects that will be used to complete the discussions. The characteristics of respondents of this research are predominantly males with the dominant age of more than 40 year-olds, working duration of more than five years, and the average number of training attended was more than 6. Further validity test results show that all items of statements are valid because they have a value greater than 0.3 . After testing the validity, the next stage is to test the reliability. The reliability test is conducted to view the consistency of the respondents' answers to the statement of the questionnaires. A construct is said to be reliable if the Cronbach Alpha value is more significant than 0.7 (Ghozali, 2013). The reliability test results demonstrate that all constructs in this research are reliable as they all have Cronbach Alpha value greater than 0.7 .

\section{RESULT}

The results of path analysis testing can be seen in table 2.

Table 2: Path Analysis Results

\begin{tabular}{lllllll}
\hline Relationship & & & Estimate & S.E. & C.R. & P \\
\hline Service_commitment & $<---$ & internal_communication & .948 & .387 & 2.446 & .014 \\
\hline Service_commitment & $<---$ & training & 1.422 & .318 & 4.478 & $* * *$ \\
\hline Relationship_quality & $<---$ & service_commitment & 1.326 & .286 & 4.640 & $* * *$ \\
\hline
\end{tabular}

Source: The data processed by the researcher

The result of path analysis in Table 2 indicates that internal communication has positive and significant effects on a commitment to customer service because the p-value is less than the significance value of 0.05 . It suggests that the better the implementation of internal communication, the more improving the commitment to customer service will be. Based on these results, it can be concluded that the first hypotheses are proven, meaning that internal communication has an 
effect on a commitment to customer service.

The effects of training on a commitment to customer service have a p-value value of 0.00 , which is smaller than the significance value of 0.05 . The result shows that training has a positive and significant effect on a commitment to customer service. It means that the more the employees attending the training, the better the commitment to customer service will be. Based on these results, it can be concluded that the second hypothesis are proven, meaning that training has an effect on the commitment to customer service.

The effects of commitment to customer service on relationship quality have a p-value value of 0.00 . The result also shows that commitment to customer service has a positive and significant effect on relationship quality. The meaning the effects are: the better the commitment to customer service, the more improving the relationship quality will be. Based on these results, it can be concluded that hypothesis 3 is proven, meaning that commitment to customer service has effects on relationship quality.

\section{Internal Communication on Commitment to Customer Service}

Internal marketing focuses on the achievement of active internal exchange of organizations and employee groups as a precondition for successful exchanges with external markets. It can improve the effectiveness and efficiency of the internal marketing program as one of the ideas of relationship marketing (Berry, 2002). Internal marketing is one of the relationship marketing strategies that should be considered in the development of a long-term relationship plan for customers (Berry, 2002). Internal marketing treats employees as internal customers, which is the process of establishing individual values in the organization to meet their needs and desire, thus to improve the employee performance and eventually to achieve the organizational goals.

The needs and desires for employees in the implementation of internal marketing, such as training and development, reward system, leadership, and internal communication, should be given to employees as internal customers of the organization. Concerning internal communication, which becomes one measurement of internal marketing as well as the variable in this research, it is found that there is a significant effect of internal communication and commitment to customer service. Internal communication occurring between institutions, in this case, is universities to employees, is proven to contribute significantly to the employee commitment to customer service, i.e., the students. As stated in the questionnaires, several universities have provided two-way communication opportunities for employees. The communication direction applied by the university is two-way communication, namely, top-down and bottom-up. Various formal \& informal meetings and events have been implemented together with many purposes, starting from program and information dissemination to the process of gathering employees' aspirations as a medium in the delivery of opinions and complaints. Besides, in the accommodation of all inputs and information from their employees, several universities have held regular meetings to discuss quality and services improvement, supported by the superiors' efforts in facilitating innovative ideas.

Communication is the process of delivering information, understanding, and comprehension from one person to another. Communication is an essential factor of organizations, as each member and sub-system in the organization must communicate with different parties to achieve their goals. The relationship between members of the organization is tied together with communication in order to form togetherness and allow the organization to carry out its functions. Communication with the organization is aimed at improving individual performance, which ultimately will improve organizational performance. Internal communication is a medium to share information and knowledge among employees, allowing them to carry out their work. Internal communication taking place within an organization is aimed at establishing a good relationship of employees, between employees and leaders, and among various subsystems. The employees are expected to feel the appreciation and attention to the internal appreciation program, thus creating a sense of belonging, motivation, creativity, and desire to achieve work performance as maximum as possible. The measurement of the employees' work success is not only limited to their work performance, but also the aspect of employees' internal communication skills within the organization. Thereby, communication with employees and many parts of subsystems in the organization is a part of the implementation of internal marketing capable of affecting employees' behavior and performance (De Bussyet al., 2003).

\section{The Training on Commitment to Customer Service}

The research results find that there is a significant effect of the training on the commitment to customer service. These training indicators are proven to contribute to employees' commitment to providing service to customers. Respondents of this research stated that they work in had allowed employees to attend the training. The training is held regularly by universities and is implemented in rotation for their employees. The training has been carried out, either those organized by the universities, which involve them in regional level training or the training held by parties or outside institutions. Also, the respondents felt that the training provided by both institutions and outside parties were able to improve the service quality provided by the employees to the students. It is also supported by the concerns of institutions that routinely inform of training offers, either those directly informed of employees or in meeting forums.

Mehra et al. (2011) proposed the importance of employee training to improve the profitability of the company, as satisfied and trained employees will better apply good service quality to satisfy the customers. The training and 
development for employees is their need to improve their skills and abilities in doing their job. Training and development are highly necessary for employees to work better in their current job, or to prepare their responsibilities in the future. Training and development are an effort to improve employee performance in a particular job that becomes their responsibility, or a job related to their work. The goal to be achieved from a training program is the improvement in individual performance, which ultimately leads to an improvement in organizational performance. Employee training and development are the overall activities to improve and develop employees' behavior (for example, knowledge, skills, job competence, productivity, discipline, attitude, and work ethic) for the achievement of the desired individual or organizational goals. Through training and development, the employees will be able to do, improve, and develop their work.

\section{The Commitment to Customer Customer Service on Relationship Quality}

The relationship quality is an assessment of relationship strength as a whole, and the extent of conformity between the needs and expectations of the parties, based on previous experiences (Crosby, Evans, \& Cowles, 1990). By Huang et al. (2013), the relationship quality consists of two constructs, namely the relationship quality of the customers and employees, and the relationship quality of the customers and organizations.

The present research employs relationship quality constructs between the customer and the organization. The final findings of this research suggest that there are significant effects of the commitment to customer service and relationship quality. Several indicators indicate that: (1) I work to improve the service quality; (2) I have ideas to improve the service quality; (3) I give suggestions to improve the service quality; (4) I always try to satisfy the students; (5) I am always willing to serve the students under any circumstances; and (6) I am all out in helping the students, \& have a significant contribution in improving the relationship quality between the institution and employees. According to Berry (1981) in Ahmed and Nahla (2014), the rational understanding of internal marketing mentions: By satisfying the company's internal customers (employees), the company will have a robust human capital and ultimately affect the service to customers. The presence of ethical commitment to employees has effects on improving the relationship quality of the employees and companies. Some other studies state that this commitment also affects the motivation and individual performance of employees. The implication of this finding suggests that organizations should respect and care with their employees as internal customers and develop good social relationships with them as internal and external customers.

\section{DISCUSSION}

The present research integrates different concepts, theories, issues, and approaches. The concept of relationship marketing is the development and maintenance of a mutually beneficial long-term relationship between the company and its employees, customers, suppliers, and other stakeholders; thus, the objectives of all parties involved are met by exchange and fulfillment of responsible promises (Gronroos, 1996). The relationship marketing perspective suggests that customers (for example, salespersons) have sustainable value, as long as they engage in the business with the company (Berry, 1983 in Morgan and Hunt, 1994).

Internal marketing, as company marketing relationship strategy (Berry, 2002), is an activity that is directed and shaped to encourage employees and salespersons to gain high performance and morality in society. Many definitions have been put forward by some researchers and academic literature. The existing definitions promote a debate about internal marketing constructs; and as a result, it is agreed that internal marketing constructs are a mix of functions from human resource and marketing management. This research is also in support of several research findings that suggest an internal marketing perspective and human resources are seen as a function and discipline of interrelated psychological theory \& organizational behavior theory (Altarifi, 2014; Rosca, 2015; DeBruin-Reynolds et al., 2015).

Internal marketing in this research uses service sectors as the object, educational services, in order to determine the role of internal marketing construct measured by using internal communication and training and its contribution to the commitment to customer service and relationship quality. The research results show that internal marketing, measured using internal communications and training, affects employees' commitment to customer service thus creating a strong relationship quality between employees and customers (students).

This research broadens our understanding of internal marketing through two dimensions, namely internal communication and training using six measurement items. The research results support the research conducted by Ahmed and Rafiq (2003), describing internal marketing as internal marketing and defining internal marketing as a controllable element of organizational management in motivating and affecting its employees. Furthermore, this research is also in favor of Chang and Chang (2008), Jouet al. (2004), and Punjaisri and Wilson (2007).

\section{CONCLUSION AND SUGGESTION}

This research identified that internal marketing and training influenced commitment to customer service, which further influenced their relationship quality. There are some empirical contributions (for academics) because this research integrates various concepts, theories, issues, and approaches. The relationship marketing concept and internal marketing model. The concept of relationship marketing is the development and maintenance of a mutually beneficial long-term relationship between the company and its employees, customers, suppliers, and other stakeholders. Meanwhile, in terms of practical contributions, the research results contribute to internal marketing practices in several universities in 62 |https://giapjournals.com/hssr/index

(c) Artanti et al. 
Surabaya, East Java, Indonesia. It will significantly affect the commitment and relationship quality. Educational institutions and institutional leadership should further promote internal marketing activities, such as vision delivery, awards, training and development, internal communication, and leadership quality so that these marketing activities can improve commitment to customer service and relationship quality.

\section{LIMITATIONS AND STUDY FORWARD}

The present research has several limitations. First, this research only uses two dimensions of internal marketing; future research is suggested to use more representative and distinctive dimensions to describe internal marketing, for example, supervisor support, satisfaction, or organizational support. Second, merely using small samples, samples in this research are limited to the education service industry, i.e., universities in one city in Indonesia, Surabaya. It is expected that future research can use the conceptual framework generated from this research and broaden the research object of other types of industries, thus producing a higher level of generalization. The selection of locations should also be more extensive and not limited to only one location or region. Three, this research employs a survey method of the cross-section. Respondents filled out the varying questionnaire at one time. The weakness of this method is that the research result does not guarantee the causal relationship between independent and dependent variables. Besides, the weakness of the cross-section survey is the tendency towards standard method bias. The score of the question item is affected by the previous score. Future research should use other research methods, such as experimental and longitudinal methods. It is based on the argument that relationship marketing, such as internal marketing and individual performance, is a timefocused process. Finally, future research is expected to more profoundly explain the effects of internal marketing on other types of outcomes, both internally and externally, from the company's external by taking the views or gaps in other internal marketing theories. Besides, research may be conducted by comparing the application of internal marketing concepts between profit and non-profit companies or comparing the two types of companies in using the concept of internal marketing actively, in the absence of internal marketing.

\section{ACKNOWLEDGMENT}

There is no financial or nonfinancial support for the study should be acknowledged.

\section{CONTRIBUTION OF AUTHOR}

Yessy Artanti created a conceptual and research framework, Widyastuti were collecting and analyze the data, Sri Hartini and Nindria Untarini analyze the data and proofreading the paper.

\section{REFERENCES}

1. Ahmed, P., Rafiq, M., \& Saad, N., (2002). Internal Marketing and the mediating role of organisational competencies. European Journal of Marketing, Vol. 37No. 9, pp. 1221-1241. https://doi.org/10.1108/03090560310486960

2. Ahmed, P. K., and Rafiq, M. (2003). Internal Marketing Issues and Challenges. European Journal of Marketing, Vol. 37 No. 9, pp. 1177-1186. https://doi.org/10.1108/03090560310498813

3. Ahmed and Nahla, (2014). Effect of Internal Marketing Adoption on the Performance of the Commercial Banks in Egypt, International Business and Social Science Research Conference.

4. Akroush, Mamoun N., ElSamen, Abu-Amjad A., Samawi, Ghazi A., and Odetallah, Abdelhadi L. (2013). Internal marketing and service quality in restaurants, Marketing Intelligent and Planning, Vol.31 No. 4, pp. 304-336. https://doi.org/10.1108/02634501311324834

5. Ali,N. (2012). An exploratory study into the implementation of internal marketing in small insurance brokers in the United Kingdom. Journal of Financial Services Marketing, Vol.17 No.3, pp. 242-254. https://doi.org/10.1057/fsm.2012.15

6. Altarifi,S. (2014).Internal marketing activities in higher education. International Journal of Business and Management, Vol.9 No.6, pp.126-140. https://doi.org/10.5539/ijbm.v9n6p126

7. Albassami, F. A., Al-Meshal, S. A., \& Bailey, A. A., (2015). An investigation of internal marketing and its effects on employees in the banking sector in Saudi Arabia. Journal of Financial Services Marketing, Vol. 20 No. 3, pp. 176-190. https://doi.org/10.1057/fsm.2015.11

8. Álvarez, L.S., Casielles, R.V. and Martín, A.M.D. (2009). The Role of Commitment Perceived by theConsumer in Service Industries, Management Research: Journal of the Iberoamerican Academy of Management, Vol. 7 Issue: 2, pp. 141-157. https://doi.org/10.2753/JMR1536-5433070204

9. Arleen Hernández-Díaz Theany Calderon-Abreu Maria Amador-Dumois Mario Córdova-Claudio. (2017). Internal marketing and customer-contact employees' attitudinal outcomes Marketing internoylasactitudes de los empleados de contacto con los clients.Academia Revista Latinoamericana de Administración, Vol. 30 Iss 1 pp. 124 - 143. https://doi.org/10.1108/ARLA-08-2015-0190

10. Asif, S. and Sargeant, A., (2000). Modelling internal communications in the financial services sector.European Journal of Marketing, Vol. 34 Issue: 3/4, pp.299-318. https://doi.org/10.1108/03090560010311867

11. Back, K. -J., Lee, C. -K., and Abbott, J., (2011). Internal Relationship Marketing: Korean Casino Employee Job Satisfaction and Organisation Commitment. Cornell Hospitality Quarterly, Vol. 52 No. 2, pp. 111-124. 
https://doi.org/10.1177/1938965510370742

12. Bailey, A., Anthony., Albassami, F., and Al-Meshal, S., (2015). The roles of employee job satisfaction and organizational commitment in the internal marketing-employee bank identification relationship. International Journal of Bank Marketing. Vol. 34. Iss 6, pp. 821-840. https://doi.org/10.1108/IJBM-06-2015-0097

13. Balaji, M.S., Roy, S.K. and Wei, K.K. (2016). Does relationship communication matter in B2C service relationships? Journal of Services Marketing, Vol. 30 Issue: 2, pp.186-200. https://doi.org/10.1108/JSM-082014-0290

14. Ballantyne, D. (2003). A relationship-mediated theory of internal marketing. European Journal of Marketing; Vol.37, No.9, pp 1242 - 1260. https://doi.org/10.1108/03090560310486979

15. Bansal, H.S., Mendelson, M.B., and Sharma, B. (2001). The impact of internal Marketing activities on external marketing outcomes. Journal of Quality Management, Vol. 6, pp. 61-76. https://doi.org/10.1016/S10848568(01)00029-3

16. Bell, S. J., Mengüç, B., and Stefani, S. L. (2004). When Customers Disappoint: A Model of Relational Internal Marketing and Customer Complaints. Journal of the Academy of Marketing Science, Vol. 32 No. 2, pp. 112116. https://doi.org/10.1177/0092070303261467

17. Bell, S.J. and Luddington, J.A. (2006). Coping With Customer Complaints.Journal of Service Research, Vol 8 No. 3, February 2006221-233. https://doi.org/10.1177/1094670505283785

18. Bennett, R., \&Barkensjo, A. (2005). Internal marketing, negative experiences, and volunteers' commitment to providing high-quality services in a UK helping and caring charitable organization. Voluntas: International Journal of Voluntary and nonprofit organizations, Vol. 16 No. 3, pp. 251-274. https://doi.org/10.1007/s11266$\underline{005-7724-0}$

19. Berry, L.L., (1981). The Employee as Customer. Journal Retail Banking, Vol. 3 No.1, pp. 25-28.

20. Berry, L.L., (1995). Relationship Marketing of Services - Growing Interest, Emerging Perspectives. Journal of the Academy of Marketing Science, Vol. 23 No. 4. https://doi.org/10.1177/009207039502300402

21. Berry, L.L. (2002). Relationship Marketing of Services-Perspectives from 1983 and 2000, Journal of Relationship Marketing, Vol. 1, No. 1, pp. 59-70. https://doi.org/10.1300/J366v01n01_05

22. Berry, L.L. and Parasuraman, A., (1991). Marketing for Services: Competing through Quality, The Free Press, New York, NY.

23. Bianchi, C. (2011). Inward internationalization of consumer services: lessons from Australian firms. Journal of Services Marketing, Vol. 25 Issue: 4, pp.282-293. https://doi.org/10.1108/08876041111143113

24. Boshoff, C. and Mels, G. (1995). A causal model to evaluate the relationships among supervision, role stress, organizational commitment and internal service quality. European Journal of Marketing, Vol. 29 Issue: 2, pp.23-42. https://doi.org/10.1108/03090569510080932

25. Bouranta, N.G.M. and Kyriazopoulos. P (2005). The Impact of Internal Marketing to Market Orientation Concept and their Effects to Bank Performance, Operational Research. An International Journal. Vol. 5 No.2, pp. 349-362. https://doi.org/10.1007/BF02944318

26. Cahill, D. (1995). The managerial implications of the learning organization: A new tool for internal marketing, Journal of Services Marketing. Vol.9, No.4, pp. 43-51. https://doi.org/10.1108/08876049510094513

27. Campo, S., Díaz, A.M. and Yagüe, M.J (2014). Hotel innovation and performance in Employee Brand Promise. Journal of Brand Management, Vol. 15, No. 1, pp. 57-70.

28. Chang, C.S., and Chang, H.C. (2008). Perceptions of Internal Marketing, Journal of Advanced Nursing, Vol. 8, No.87, pp. 92-100. https://doi.org/10.1111/j.1365-2648.2008.04844.x

29. Caruana, A., \& Calleya, P. (1998). The effect of internal marketing on organisational commitment among retail bank managers. International Journal of bank marketing, Vol. 16 No.3, pp. 108-116. https://doi.org/10.1108/02652329810213510

30. Chi, H.K., Yeh, H.R. and Chiou C . Y . (2008). The Mediating Effects of Internal Marketing on Transformational Leadership and Job Performance of Insurance Salespersons in Taiwan.TheBusiness Review, Vol. 11 December; No. 1.

31. Collins, B., \& Payne, A. (1991). Internal marketing: a new perspective for HRM, European Management Journal, Vol. 9 No.3, pp. 261-270. https://doi.org/10.1016/0263-2373(91)90006-C

32. Conduit, J and Mavondo. F.T. (2001). How Critical Is Internal Customer Orientation to Market Orientation? Journal of Business Research, 51 (January), pp.11-24. https://doi.org/10.1016/S0148-2963(99)00044-2

33. Crosby, Lawrence A., Kenneth R. Evans, and Deborah Cowles. 1990. Relationship Quality in Services Selling: An Interpersonal Influence Perspective. Journal of Marketing, Vol.54 No.3, pp. 68-81. https://doi.org/10.1177/002224299005400306

34. De Bussy, N. M., Ewing, M. T., \& Pitt, L. F. (2003). Stakeholder theory and internal marketing communications: a framework for analysing the influence of new media. Journal of marketing communications, Vol.9 No.3, pp. 147-161. https://doi.org/10.1080/1352726032000129890

35. De Bruin-Reynolds, L., Roberts-Lombard, M. and de Meyer, C. (2015). The traditional internal marketing mix and its perceived influence on graduate employee satisfaction in an emerging economy.Journal of Global Business and Technology, Vol.1 No.1, pp. 24-38.

36. Dias, M.G. and da Silva, C. (2013). EndomarketingemumaUniversidadeComunitária: Uma Análise a partirdas 
percepções dos colaboradores/Internal marketing in a Community University: an analysis based on the perceptions of administrative technicians. SINERGIA-Revista do Institutode Ciências Econômicas, Administrativas e Contábeis, Vol 17 No.2, pp. 77-86.

37. Donabedian, A. (1980). Explorations in Quality Assessment and Monitoring, Volume I: The Definition of Quality and Approaches to Its Assessment, Health Administration Press, Ann Arbor, MI.

38. Du Preez, R., \& Bendixen, M. T., (2015). The impact of internal brand management on employee job satisfaction, brand commitment and intention to stay. International Journal of Bank Marketing, Vol.33 No.1, pp. 78-91. https://doi.org/10.1108/IJBM-02-2014-0031

39. Dwyer, F.R., Schurr, P.H. and Oh, S. (1987).Developing Buyer-Seller Relationships, Journal of Marketing, 51, April, pp.11-27. https://doi.org/10.1177/002224298705100202

40. Ewing, M. T., \& Caruana, A. (1999). An internal marketing approach to public sector management: the marketing and human resources interface. International Journal of Public Sector Management, Vol.12 No.1, pp. 17-29. https://doi.org/10.1108/09513559910262652

41. Frandsen, F. and Johansen, W. (2011). The study of internal crisis communication: towards an integrative framework. Corporate Communications: An International Journal, Vol. 16 Issue: 4, pp.347-361. https://doi.org/10.1108/13563281111186977

42. Fullerton, G. (2014).The moderating effect of normative commitment on the service quality-customer retention relationship.European Journal of Marketing, Vol. 48 Issue: 3/4, pp.657-673. https://doi.org/10.1108/EJM-062011-0333

43. Furtmueller, E., Dick, R.V. and Wilderom, C. (2011).Service behaviours of highly committed financial consultants. Journal of Service Management, Vol. 22 Issue: 3, pp.317-343. https://doi.org/10.1108/09564231111136854

44. Garbarino, E., \& Johnson, Mark S. (1999). The Different Roles of Satisfaction, Trust, and Commitment in Customer Relationships. Journal of Marketing, Vol.63 No.2 (April), pp. 70-87. https://doi.org/10.1177/002224299906300205

45. George, W. R. (1990). Internal marketing and organizational behavior: A partnership in developing customerconscious employees at every level. Journal of Business research, Vol. 20 No.1, pp. 63-70. https://doi.org/10.1016/0148-2963(90)90043-D

46. George, J.M. (1998).Salesperson Mood at Work: Implication for Helping Customers. Journal of Personal Selling \& Sales Management, 18 (Summer), pp. 23-30.

47. Ghozali, I.(2013). Model PersamaanStruktural, Konsep dan AplikasiDengan Program AMOS 21. 5 ed. Semarang, Indonesia: Badan PenerbitUndip.

48. Giovanis, A. (2016).Consumer-brand relationships' development in the mobile internet market: Evidence from an extended relationship commitment paradigm. Journal of Product \& Brand Management, Vol. 25 Issue: 6, pp.568-585. https://doi.org/10.1108/JPBM-05-2015-0884

49. González, G.B., Sasaki, I. and Zamora, D.T. (2016).Understanding the impact of internal marketing practices on both employees ' and managers ' organizational commitment in elderly care homes. Journal of Service Theory and Practice, Vol. 26 Issue: 1, pp.28-49. https://doi.org/10.1108/JSTP-09-2014-0216

50. Goolsby, J.R. and Hunt, S.D. (1992).Cognitive Moral Development and Marketing. Journal of Marketing; January, Vol. 56 No.1, pp. 55. https://doi.org/10.1177/002224299205600106

51. Gounaris, S.P. (2006).Internal-market orientation and its measurement. Journal of Business Research, Vol. 59, No. 4, pp. 432-448. https://doi.org/10.1016/j.jbusres.2005.10.003

52. Gray, B. J. (2006). Benchmarking Services Branding Practices. Journal of Marketing Management, Vol.22 No.(7/8), pp. 717-758. https://doi.org/10.1362/026725706778612095

53. Gronroos, C. (1981). Internal marketing - an integral part of marketing theory. in Donnelly, J.H. and George, W.E. (Eds), Marketing of Services, American Marketing Association Proceedings Series, pp. 236-238.

54. Gronroos, C. (1990). Relationship Marketing: The Strategy Continuum. Journal of the Academy of Marketing Science, Vol. 23 No. 4, pp. 252-5. https://doi.org/10.1007/BF02893863

55. Grönroos, C. (1996). Relationship marketing: strategic and tactical implications. Management decision, Vol.34 No.(3), pp. 5-14. https://doi.org/10.1108/00251749610113613

56. Ha, NC., Bakar, R.A. and Jaafar, S.I.S. (2007).Internal Marketing Issues in Service Organizations in Malaysia. International Review of Business Research Papers, Vol.3 No.5 pp. 134-145.

57. Hemsley-Brown, J. and Oplatka, I. (2006). Universities in a competitive global marketplace: A systematic review of the literature on higher education marketing. International Journal of Public Sector Management, Vol.19. No.4. pp.316-338. https://doi.org/10.1108/09513550610669176

58. Huang, Jin-An. Weng, Rhay-Hung, Lai, Chi-Shiun, and San-Hu, Jer. (2012).Perceptual Market Orientation Gap and Its Impact on Relationship Quality and Patient Loyalty: The Role of Internal Marketing. Evaluation and The Health Professions, Vol.36 No.92, pp. 204-227. https://doi.org/10.1177/0163278712458797

59. Huang, Y. T., and Rundle-Thiele, S. (2013), Exploring Internal Marketing Measurement, Working paper. Griffith University.

60. Huang, Y.T., and Rundle-Thiele, S. (2015). A holistic management tool for measuring internal marketing activities. Journal of Service Marketing, Vol. 29 Iss 6/7, pp. 571-584. https://doi.org/10.1108/JSM-03-2015- 
0112

61. Huang, J.A., Tsai, W.C., Chen, Y.C., Hu, W.H., and Yang,D.Y. (2003). Factors associated with frequent use of emergency services in a medical center. Journal of the Formosan Medical Association,Vol. 102, pp. $222-228$.

62. Huang, J.-A., Hu, J.-S., Lai,C.-S., and Weng, R. -H. (2011). The impact of market Orientate on the physicianpatient relationship: Aqualitative analysis. The Journal of Health Sciences, Vol. 13,pp. 48-61.

63. Hunt, S.D., Wood, V.R. and Chonko, L.B. (1991). Corporate Ethical Values and Organizational Commitment in Marketing. The Journal of Marketing, Vol. 53, No. 3 (July), pp. $79 \quad-90$. https://doi.org/10.1177/002224298905300309

64. Hwang, I.S. and Chi. D.J. (2005).Relationships among Internal Marketing, Employee Job Satisfaction and International Hotel Performance: An Empirical Study. International Journal of Management Vol. 22 No. 2, pp. 285.

65. Izogo, E.E. (2017).Customer loyalty in telecom service sector: the role of service quality and customer commitment. The TQM Journal, Vol. 29 Issue: 1, pp.19-36. https://doi.org/10.1108/TQM-10-2014-0089

66. Jones, T.D., Taylor, S.F. and Bansal, H.S. (2009).Targets of commitment in service provider consumer relationships: a prototyping study. Qualitative Market Research: An International Journal, Vol. 12 Issue: 1 , pp.36-48. https://doi.org/10.1108/13522750910927205

67. Jou, J.Y., Chou, C.K., and Fu, F.L. (2008). Development of an Instrument to Measure Internal Marketing Concept. Journal of Applied Management and Entrepreneurship, Vol. 13, No. 3, pp.66-79.

68. Joung, H.W., Goh, B.K., Huffman, L., Yuan, J.J. and Surles, J. (2015). Investigating relationships between internal marketing practices and employee organizational commitment in the foodservice industry. International Journal of Contemporary Hospitality Management, Vol. 27 No. 7, pp 1618-1640. https://doi.org/10.1108/IJCHM-05-2014-0269

69. Keller, S.B., Lynch, D.F., Ellinger, A.E. and Ozment, J. (2006).The Impact of internal Marketing Efforts In Distribution Service Operations. Journal of Business Logistics; Vol.27, No.1; pp. 109. https://doi.org/10.1002/j.2158-1592.2006.tb00243.x

70. Kitchen, P.J and Daly, F. (2002).Internal communication during change management. Corporate Communications: An International Journal, Vol. 7 Issue: 1, pp.46-53. https://doi.org/10.1108/13563280210416035

71. Kollat, J. and Farache, F. (2017). Achieving consumer trust on Twitter via CSR communication. Journal of Consumer Marketing, Vol. 34 Issue: 6, pp.505-514. https://doi.org/10.1108/JCM-03-2017-2127

72. Koskela, I. and Palukka, H. (2011). Trainer interventions as instructional strategies in air traffic control training. Journal of Workplace Learning, Vol. 23 Issue: 5, pp.293-314. https://doi.org/10.1108/13665621111141902

73. Lings, I.. and Brooks, R. (1998).Implementing and measuring the effectiveness of internal marketing .Journal of Marketing Management, Vol.14, pp. 325-351. https://doi.org/10.1362/026725798784959426

74. Little, M.K. and Dean, A.M. (2006).Links between service climate, employee commitment and employees' service quality capability. Managing Service Quality: An International Journal, Vol.16 Issue: 5, pp.460-476. https://doi.org/10.1108/09604520610686133

75. Mechanic, D., \& Meyer, S. (2000). Concepts of trust among patients with serious illness. Social Science and Medicine, Vol.51 No.5, pp. 657-668. https://doi.org/10.1016/S0277-9536(00)00014-9

76. Mehra, S., Joyal, A.D., \& Rhee, M. (2011). On adopting quality orientation as an operations philosophy to improve business performance in banking services. International Journal of Quality \& Reliability Management, Vol.28 No.9, pp. 951-968. https://doi.org/10.1108/02656711111172531

77. Money, A. H., \& Foreman, S. (1996). The measurement of internal marketing: a confirmatory case study. Journal of Marketing Management, Vol.11 $\quad$ No.(8), $\quad$ pp. https://doi.org/10.1080/0267257X.1995.9964388

78. Moreira, A.C. and Silva, P.M. (2015). The trust-commitment challenge in service quality-loyalty relationships. International Journal of Health Care Quality Assurance, Vol. 28 Issue: 3, pp.253-266. https://doi.org/10.1108/IJHCQA-02-2014-0017

79. Morgan, R. M., \& Hunt, S. D. (1994). The commitment-trust theory of relationship marketing. Journal of Marketing, Vol. 58 No.3, pp. 20-38. https://doi.org/10.1177/002224299405800302

80. Morrison, E.W. (1996). Organizational Citizenship Behaviors as a Critical Link Between HRM Practices and Service Quality. Human Resources Management 35 (Winter), pp. 493-512 https://doi.org/10.1002/(SICI)1099050X(199624)35:4<493::AID-HRM4>3.0.CO;2-R

81. Mouawad, M. and Kleiner, B.H. (1996). New developments in customer service training. Managing Service Quality: An International Journal, Vol. 6 Issue: 2, pp.49-56. https://doi.org/10.1108/09604529610109774

82. Mudie, P. (2003). Internal customer: By design or by default. European Journal of Marketing, Vol.37 No.9, pp.1261-1276. https://doi.org/10.1108/03090560310486988

83. Narteh, B. (2012). Internal marketing and employee commitment: Evidence from the Ghanaian banking industry. Journal of Financial Services Marketing,Vol.17 No.4, pp.284-300. https://doi.org/10.1057/fsm.2012.22

84. Naude, P.; J.Desai; and J.Murphy (2003). Identifying the Determinants Of Internal Marketing Orientation. European Journal of Marketing, Vol.37 No.9, pp. 1205-1220. https://doi.org/10.1108/0390560310486951 
85. Panigyrakis, G.G. and Theodoridis, P.K. (2009). Internal marketing impact on business performance in a retail context. International Journal of Retail and Distribution Management, Vol. 37 No. 7, pp. 600-628. https://doi.org/10.1108/09590550910964620

86. Papasolomou, I., \&Vrontis, D. (2006). Building corporate branding through internal marketing: the case of the UK retail bank industry. Journal of product \& brand management, Vol.15 No.(1), pp. 37-47. https://doi.org/10.1108/10610420610650864

87. Paraskevas, A. (2001). Internal Service Encounters in Hotels: An Empirical Study. International Journal of Contemporary Hospitality Management, Vol.13 No.6, pp. 285-29. https://doi.org/10.1108/09596110110400481

88. Patwardhan, A. and Patwardhan, P. (2009). Are consumer surveys valuable as a service improvement tool in health services? A critical appraisal. International Journal of Health Care Quality Assurance, Vol. 22 Issue: 7 , pp.670-685. https://doi.org/10.1108/09526860910995010

89. Prasad, A. and Steffes, E. (2002).Internal marketing at Continental Airlines: Convincing employees that management knows best. Marketing Letters, Vol.13, No.2, pp. 75-89. https://doi.org/10.1023/A:1016009201552

90. Peccei, R., \& Rosenthal, P. (1997). The antecedents of employee commitment to customer service: evidence from a U.K. Service context. The International Journal of Human Resource Management, Vol. 8, No. 1, pp. 6686. https://doi.org/10.1080/09585199700000041

91. Piercy, N. and N. Morgan.(1990). Internal marketing: making marketing happen, Marketing Intelligence and Planning, Vol.8 No.1, pp. 4-6. https://doi.org/10.1108/EUM0000000001069

92. Piercy, N. F. (1995). Customer satisfaction and the internal market: marketing our customers to our employees. Journal of Marketing practice: Applied marketing science, Vol.1 No.1, pp. 22-44. https://doi.org/10.1108/EUM0000000003878

93. Preez, R.D. and Bendixen, M.T. (2015).The impact of internal brand management on employee job satisfaction, brand commitment and intention to stay. International Journal of BankMarketing,Vol.33, No.1, pp.78-91. https://doi.org/10.1108/IJBM-02-2014-0031

94. Punjaisri, K., and Wilson, A. (2007). The Role of Internal Branding in the Delivery of times of crisis. International Journal of Contemporary Hospitality Management, Vol. 26 No. 8, pp. 12921311.

95. Quester, P. G. and Kelly, A. (1999).Internal Marketing Practices in the Australian Financial Sector: An Exploratory Study. Journal of Applied Management Studies, Vol.8 No.2, pp.21.

96. Rafiq, M.. and Ahmed, P.K. (1993).The scope of internal marketing: Defining the boundary between marketing and human resource management. Journal of Marketing Management, 9(3), pp.219- 232. https://doi.org/10.1080/0267257X.1993.9964234

97. Rafiq, M. and Ahmad, R.M. (2000).Advances in Internal Marketing: Definition, Synthesis and Extension. Journal of Services Marketing, Vol.14 No.6, pp.449-462. https://doi.org/10.1108/08876040010347589

98. Rosca, V. (2015). Linking human resources with internal marketing in foot ball management. RevistaDe Management Comparat International, Vol.16. No.3, pp. 372-384

99. Sahi, G.K., Lonial, S., Gupta, M. and Seli, N. (2013). Revisiting internal market orientation: Anote. Journal of Services Marketing, Vol.27. No.5, pp. 385-403. https://doi.org/10.1108/JSM-09-2011-0131

100.Salehzadeh., Reza., Pool, J.K., Tabaeeian, R.A., Amani, M. and Mortazavi, M. (2017). The Impact of Internal Marketing and Market Orientation on Performance: An Empirical Study in Restaurant Industry. Measuring Business Excellence Hospitality Management, Vol. 27 No. 7, pp. 1618 1640. https://doi.org/10.1108/MBE-022016-0009

101.Schwepker, C.H.Jr. and Good, D . J . (2011).Moral Judgment and its Impact on Business-to- Business Sales Performance and Customer Relationships. Journal of Business Ethics; Vol.98, pp. 609-625. https://doi.org/10.1007/s10551-010-0641-8

102. Sharma, N. and Patterson, P.G. (1999). The impact of communication effectiveness and service quality on relationship commitment in consumer, professional services. Journal of Services Marketing, Vol. 13 Issue: 2 , pp.151-170. https://doi.org/10.1108/08876049910266059

103. Sheth, J.N. and Parvatiyar, A. (2002). Evolving Relationship Marketing into a Discipline. Journal of Relationship Marketing, Vol. 1, No.1, pp 3-16. https://doi.org/10.1300/J366v01n01 02

104.Shiu, Y. M., \& Yu, T. W. (2010). Internal marketing, organisational culture, job satisfaction, and organisational performance in non-life insurance. The Service Industries Journal, Vol. 30 No.6, pp. 793-809. https://doi.org/10.1080/02642060701849840

105. Štimac, H. and Šimić, M.L. (2012). Competitiveness in higher education: A need for marketing orientation and service quality. Economics and Sociology, Vol.5 No.2, pp. 23-34. https://doi.org/10.14254/2071-789X.2012/5$\underline{2 / 2}$

106. Suh, T. and Lee, J. (2016). Internal audience segmentation and diversity in internal communication. Corporate Communications: An International Journal, Vol. 21 Issue: 4, pp.450-464. https://doi.org/10.1108/CCIJ-052015-0024

107.Tareef, F. and Balas, A. (2012). Marketing in higher education institutes: Using an internal marketing strategy and innovation models. Managerial challenges of the contemporary society, Proceedings, BabesBolyai University, Cluj-Napoca, Vol. 3, pp.163-169. 
108.Taylor, C. (1994). Baldrige Winners Committed to Service Quality. Managing Service Quality: An International Journal, Vol. 4 Issue: 2, pp.26-30. https://doi.org/10.1108/09604529410796170

109. Thomson, K. and Hecker, L. (2001). Value adding communication: Innovation in employee communication and internal marketing. Journal of Communication Management, Vol. 5 Issue: 1,pp.48-58. https://doi.org/10.1108/13632540110806668

110. Varey, R.J. (1995). Internal marketing: A review and some interdisciplinary research challenges. International Journal of Service Industry Management, Vol. 6 No. 1, pp. 40-63. https://doi.org/10.1108/09564239510078849

111. Varey, R. and Lewis, B. (1999). A broadened conception of internal marketing. European Journal of Marketing, Vol.33, No.9/10, pp. 926-944. https://doi.org/10.1108/03090569910285869

112.VicentTortosa Edo JaumeLlorens-Monzonís Miguel ÁngelMoliner-Tena Javier Sánchez-García (2015). The influence of internal market orientation on external outcomes. Journal of Service Theory and Practice, Vol. 25 Iss 4 pp. 486 - 523. https://doi.org/10.1108/JSTP-11-2013-0259

113.Wayne, S. J., Shore, L. M., \& Liden, R. C. (1997). Perceived organizational support and leader-member exchange: A social exchange perspective. Academy of Management Journal, Vol.40, pp. 82-111. https://doi.org/10.2307/257021

114. Wetzels, M., Ruyter, K.D. and Birgelen, M.V (1998). Marketing service relationships: the role of commitment. Journal of Business \& Industrial Marketing, Vol. 13 Issue: 4/5, pp.406-423. https://doi.org/10.1108/08858629810226708

115.Zaman, K., Javaid, N., Arshad, A. and Bibi, S. (2012).Impact of Internal Marketing on Market Orientation and Business Performance. International Journal of Business and Social Science, Vol.3 No. 12 (Special Issue), pp. 76.

116.Zampetakis, L.A. and Moustakis, V. (2007).Fostering corporate entrepreeurship through internal marketing Implications for change in the public sector. European Journal Innovation, 10(4),pp.21. https://doi.org/10.1108/14601060710828754 